\title{
Evaluation of the antiplasmodial properties of selected plants in southern Ethiopia
}

\author{
Solomon Asnake ${ }^{1}$, Tilahun Teklehaymanot ${ }^{2}$, Ariaya Hymete ${ }^{3}$, Berhanu Erko ${ }^{2}$ and Mirutse Giday ${ }^{2 *}$
}

\begin{abstract}
Background: The majority of the Ethiopian population is at risk of malaria largely caused by Plasmodium falciparum. The resistance of the parasite to existing drugs is the main challenge in the control of the disease and thus new therapeutic drugs are required. In Ethiopia, people use different plant species to treat malaria. However, very few of them have so far been evaluated for their safety level and antimalarial activity. Thus, the aim of this study was to evaluate the safety and antimalarial activity of extracts of Ajuga integrifolia, Clerodendrum myricoides, Melia azedarach, Peponium vogelii and Premna schimperi, locally used by the Sidama people of Ethiopia to treat malaria.

Methods: The safety level of $80 \%$ methanol extracts of the plants were evaluated using standard acute toxicity test procedure. The antiplasmodial activity of $80 \%$ methanol extracts of the plants were assessed in vivo using Swiss albino mice against chloroquine sensitive rodent malaria parasite, Plasmodium berghei, using the standard 4-day suppressive test procedure at doses of 200,400 and $800 \mathrm{mg} / \mathrm{kg} /$ day. The $80 \%$ methanol extract of Ajuga integrifolia that exhibited better antimalarial activity was fractionated using different solvents and screened for its phytochemical constituents and evaluated in vivo for its antimalarial activity at doses of 100, 200 and $400 \mathrm{mg} / \mathrm{kg} /$ day.

Results: All extracts given at the three different doses caused no lethal effect on mice in $24 \mathrm{~h}$ and within 10 days of observation. All extracts and fractions exhibited antimalarial activity in a dose dependant manner. The highest inhibition was exhibited by the crude extracts of $A$. integrifolia $(35.17 \%)$ at $800 \mathrm{mg} / \mathrm{kg} / \mathrm{day}(P<0.05)$. Among fractions of A. integrifolia, n-butanol fraction demonstrated the highest inhibition $(29.80 \%)$ at $400 \mathrm{mg} / \mathrm{kg} /$ day $(P<0.05)$. The extracts and fractions prolonged the survival time and prevented weight loss of the mice, but did not prevent PCV reduction. Phytochemical test on Ajuga integrifolia indicated the presence of alkaloids, flavonoids, saponins, terpenoids, anthraquinone, steroids, tannins, phenols and fatty acids.
\end{abstract}

Conclusions: Findings show that the plants are non-toxic and demonstrate antimalarial activity in a dose dependant manner suporting claims of their traditional therapeutic value for malaria treatment. However, further in-depth investigation is required to assess the potential of the plants towards the development of new antimalarial agent.

Keywords: Antimalarial plants, Plasmodium berghei, Sidama people, Ethiopia

\section{Background}

Malaria continues to be a leading cause of morbidity and mortality in sub-Saharan African countries, especially among children under the age of five and pregnant women [1]. Besides its major public health problem, the disease also has negative impact on socioeconomic development. Malaria mostly affects people in productive age groups and causes substantial economic loss because

\footnotetext{
* Correspondence: mirutseg@yahoo.com

${ }^{2}$ Aklilu Lemma Institute of Pathobiology, Addis Ababa University, P.O. Box

1176, Addis Ababa, Ethiopia

Full list of author information is available at the end of the article
}

of the compromised capacity and efficiency of the labour force [2].

Malaria is a major public health problem in Ethiopia; more than $60 \%$ of the Ethiopian population is at risk of malaria and approximately $62 \%$ of malaria cases are due to P. falciparum [3]. Malaria was the leading cause of morbidity and mortality in the years 2002, 2003 and 2004 [4]. However, since 2005 the incidence of malaria and death in the country has declined due to scale up of intervention strategies together with the administration of artemisin combination therapy (ACT) [5]. However, 
the parasite is less sensitive to antimalarial drugs such as chloroquine, amodiaquine and sulphadoxine pyrimethamine [6]. There are also reports on parasite resistance to currently existing first line drug regimen ACT in parts of Cambodia and Thailand [7] as well as reduced sensitivity in parts of Africa [8]. Such reports necessitate a search for new and effective antimalarial drug.

Traditional medicinal remedies are viable treatment alternatives for communities that lack access to available drugs and they provide an opportunity to introduce novel antimalarials too. Medicinal plants served as source of two major antimalarial drugs, quinine from Peruvian medicinal plant Cinchona succirubra tree bark and artemisinin from Chinese medicinal plant Artemisia annua [9].

In Ethiopia, there is a widespread use of traditional medicine among urban and rural population, which might be related to accessibility, cultural acceptability and economic affordability of the system as compared to modern medicine [10]. Investigations carried out in the country indicated that traditional healers and indigenous people in different parts of the country utilize different species of medicinal plants [11-15] for treatment of malaria. There are still more other medicinal plants that are claimed to be effective by local communities in Ethiopia but not documented and evaluated for their safety level and antimalarial activity. Thus, the purpose of this study was to evaluate the antiplasmodial properties of Ajuga integrifolia, Clerodendrum myricoides, Melia azedarach, Peponium vogelii and Premna schimperi used by the Sidama people, southern Ethiopia and fraction of Ajuga integrifolia. The five plants were the ones that had the highest relative frequency of citation (RFC) as revealed from an ethnobotanical study conducted in Boricha District, Sidama Zone of the South Region of Ethiopia by the same investigators involved in the current study. According to Trotter and Logan [16], plants that are used in some repetitive fashion are more likely to be biologically active. Previous studies conducted on the plants indicated their antiplasmodial activity [17-19]. An in vivo study conducted on water extract of Ajuga remota, a close relative of $A$. integrifolia treated mice showed $90.4 \%$ parasitaemia suppression at a dose of $30 \mu \mathrm{g} / \mathrm{mL}$ [17]. Aqueous, methanol and dichloromethane extracts of the root bark of $C$. myricoides exhibited in vitro antimalarial activity with $\mathrm{IC}_{50}$ values of $64 \mu \mathrm{g} / \mathrm{mL}, 48.2 \mu \mathrm{g} / \mathrm{mL}, 15 . \mu \mathrm{g} / \mathrm{mL}$, respectively [18]. A study conducted on bark extract of $M$. azedarach revealed an in vitro antimalarial activity with $\mathrm{IC}_{50}$ value of $66.2 \mu \mathrm{g} / \mathrm{mL}$ [19]. Study carried out on crude methanol extract and fractions of petroleum ether, dichloromethane and ethyl acetate of the bark of Premna angolensis, relative species of $P$. schimperi, indicated antimalarial activity with $\mathrm{IC}_{50}$ values of $180,250,250$ and $250 \mu \mathrm{g} / \mathrm{mL}$, respectively [20]. Phytochemical screening conducted on C. myricoides showed the presence of secondary metabolites such as saponins, phytosteroides, polyphenols, flavonoides, tannins and alkaloids [21].

\section{Methods \\ Plant collection}

For the in vivo test, samples of Ajuga integrifolia, Clerodendrum myricoides, Melia azedarach, Peponium vogelii and Premna schimperi were collected from Boricha District, southern Ethiopia, during one of the field trips to the area. Specimen of each plant was dried, identified at Aklilu Lemma Institute of Pathobiology and National Herbarium of Addis Ababa University and voucher deposited at the National Herbarium.

\section{Preparation of crude extracts}

Parts of the plant samples were shade dried, ground using electric grinding mill (Laboratory mill, Arthuur A. Thomas company Philadelphia, USA), sieved by using sieve number 85 , weighed using electronic balance and placed in plastic bags until extraction. One hundred gram of each powdered medicinal plant part was extracted with $500 \mathrm{~mL}$ of $80 \%$ methanol using a soxhlet extractor [22]. Then, methanol was removed using rotary evaporator at a temperature of about $40-45{ }^{\circ} \mathrm{C}$ and the water part was removed using freeze dryer (lyophilizer). The dried extract of each plant part was collected in labeled airtight small bottles and kept in deep freezer until used.

\section{Fractionation of crude extracts}

Ajuga integrifolia, a plant with better antimalarial effect, was further fractionated using solvent fractionation technique [23]. Sequential solvent partitioning of the $80 \%$ methanol crude extract was conducted to get different solvent fractions. Twenty grams of the extract was suspended in $350 \mathrm{~mL}$ of distilled water in a separatory funnel. The aqueous portion was partitioned three to four times with $100 \mathrm{~mL}$ of chloroform to obtain chloroform fraction. Then, aqueous residue was further fractionated three to four times with $100 \mathrm{~mL}$ of $\mathrm{n}$-butanol to obtain $\mathrm{n}$-butanol fraction. Finally, the aqueous solution was collected as the third fraction. The chloroform and nbutanol fractions were concentrated in a rotary evaporator. The aqueous fraction was frozen in refrigerator overnight and then, dried using a lyophilizer. The fractions obtained were put in airtight bottles and stored in a refrigerator at $4{ }^{\circ} \mathrm{C}$ until used.

\section{Phytochemical screening}

Phytochemical screening to test for the presence of secondary metabolites (alkaloids, terpenoids, flavonoids, tannins, saponins, steroids, anthraquinon and phenols) 
and proteins, carbohydrates, and fats and oils in the crude extract of $A$. integrifolia was carried out using standard procedures [24].

\section{In vivo acute toxicity test}

Acute toxicity test of the extracts was conducted in Swiss albino male mice of six to eight weeks of age and weighing $25-30 \mathrm{~g}$. The test was performed by randomly dividing 30 mice into six groups of five mice per cage. The mice were fasted over night and groups 1 to 5 received $2000 \mathrm{mg} / \mathrm{kg}$ of the extract, whereas control (group 6) mice received the vehicle, distilled water [25]. Then, the mice were observed for any gross behavioral change and death one hour after the treatment, intermittently for four hours, and thereafter over a period of $24 \mathrm{~h}$. The mice were further observed for 10 days.

\section{In vivo antimalarial test}

The test was carried out based on the four-day suppressive test described by Peters et al. [26]. Male Swiss albino mice weighing 25-30 g were put randomly into test and control groups, each group containing five mice and were supplied with adequate amount of mouse cubes and clean drinking water. The plasmodium strain used for the test was $P$. berghei, a chloroquine sensitive rodent malaria parasite, obtained from the Drug Research Department of the Ethiopian Public Health Institute. The parasitized erythrocytes for each test were collected from an infected donor mouse with rising parasitaemia of 20$30 \%$. The mice were sacrificed by head blow, and blood was collected in a Petri dish with an anticoagulant ( $0.5 \%$ trisodium citrate) by severing the jugular vein.

The blood was then diluted with physiological saline $(0.9 \%)$ in proportion of 1:4. Each mouse was then inoculated with $0.2 \mathrm{~mL}$ of blood containing about $10^{7} \mathrm{P}$. berghei infected erythrocytes on day 0 through intra peritoneal route. After three hours of parasite inoculation, three test groups of mice were administered with 200,400 and $800 \mathrm{mg} / \mathrm{kg}$ of the crude extracts. Similarly, in fraction treated mice, three test groups of infected mice were treated with 100,200 and $400 \mathrm{mg} / \mathrm{kg}$ of the fractions. The negative control group mice were treated with $0.2 \mathrm{~mL}$ of the vehicle (distilled water) and the positive control groups were treated with $10 \mathrm{mg} / \mathrm{kg}$ of chloroquine.

\section{Determination of parasitaemia}

On the fifth day, a drop of blood was taken from tail snip of each mouse on frosted slide and smears were prepared, fixed with methanol and stained with $10 \%$ Giemsa solution at pH 7.2 for $15 \mathrm{~min}$. Then, five fields were randomly selected on each stained slide and examined under microscope with an oil immersion objective ( $\times 100$ magnification power). The parasitaemia level was determined by counting the number of parasitized erythrocytes on randomly selected fields of the slide. Percentage of parasitaemia and suppression was calculated using the formulas [27] given below.

$$
\begin{aligned}
& \% \text { Parasitaemia }=\frac{\text { Number of parasitized RBCx100 }}{\text { Total number of RBC counted }} \\
& \% \text { of suppression }\left(\begin{array}{c}
\text { Parasitaemia in negative control } \\
\text {-Parasitaemia in treated group }
\end{array}\right) \times 100 \\
& \text { Parasitaemia in negative control }
\end{aligned}
$$

\section{Determination of mean body weight and survival time}

The body weight was determined by taking average weight of mice in each test group and comparing it with that of infected negative controls. Mortality was monitored daily and the number of days from the time of inoculation of the parasite up to death was recorded for each mouse in the treatment and control groups throughout the follow up period. The mean survival time (MST) for each group was calculated as given below.

$$
\text { MST }=\frac{\text { Sum of survival time (days) of mice in group }}{\text { Total numbers of mice in that group }}
$$

\section{Determination of the packed cell volume (PCV)}

Blood was collected from sniped tail of each mouse in heparinized microhaematocrit capillary tubes. Each capillary tube was sealed by crystal seal and placed in a micro-hematocrit centrifuge (Hettich haematokrit, Germany) with the sealed ends out wards. Blood that was filled to three fourth of the capillary tubes was centrifuged at 12,000 rpm for $5 \mathrm{~min}$. The volume of the total blood and the volume of erythrocytes were measured and PCV was calculated using the formula:

$$
\mathrm{PCV}=\frac{\text { Volume of RBC in a givenblood volumex } 100}{\text { Total blood volume }}
$$

\section{Data analysis}

The collected data were organized, entered into Microsoft Office Excel 2007 and exported to Windows SPSS 20.1. Frequencies and percentages were calculated from the data using the Excel 2007. Data on parasitaemia, survival day, body weight and packed cell volume were analyzed using Windows SPSS version 20.1. One way ANOVA and paired sample $t$-test were used to compare results within groups for difference between initial (before) and final (after) treatments. Results obtained from the study were presented as mean plus or minus standard error of the mean $(\mathrm{M} \pm \mathrm{SEM})$. All data were analyzed at $95 \%$ confidence interval $(\alpha=0.05)$. 


\section{Results}

\section{Percentage yield of extracts}

The yield of the extracts obtained from the five antimalarial plants was in the range of 10-50 g. The highest percentage of yield was obtained from $A$. integrifolia (30.0\%) and the lowest from P. schimperi (18.0\%) (Table 1). The physical nature of the extracts showed that crude extracts of leaf and areal parts were semi solid (gumy), while extracts from bark were solid.

\section{Acute toxicity test of crude extracts}

Acute toxicity test conducted to determine the safety level of crude extracts of the five plants showed that the lethal dose of all extracts was above $2000 \mathrm{mg} / \mathrm{kg}$. All extracts that were administered orally in a single dose of $2000 \mathrm{mg} / \mathrm{kg}$ to the laboratory bred Swiss albino mice caused no lethal effect within $24 \mathrm{~h}$ of the observation period. The gross behavioral and physical observation of the experimental mice also revealed that the extracts created no visible signs of acute toxicity such as lacrimation, hair erection and reduction in their motor and feeding activities. The mice were physically active and fed and drunk as that of the control groups administered with the vehicle (distilled water) within the observation period of 10 days.

\section{In vivo antimalarial test of crude extracts}

Result of the four-day suppressive test of the crude extracts of the five antimalarial plants at different dose levels on mice infected with $P$. berghei expressed as percent of reduction of parasitaemia in reference to the negative control mice is summarized in Table 2 . The result indicated that all the crude extracts of the five antimalarial plants exhibited antiplasmodial activity. The extracts reduced parasitaemia to different levels in dose dependant manner. The highest inhibition was exhibited by crude extract of $A$. integrifolia $(35.17 \pm 1.95)$ at $800 \mathrm{mg} / \mathrm{kg} /$ day and the lowest by Premna schimperi $(2.27 \pm 0.07)$ at $200 \mathrm{mg} / \mathrm{kg} /$ day.

Comparison of each test group to their respective negative control groups at different dose level indicated that the crude extracts of $A$. integrifolia reduced parasitaemia to significant level on day $4(p<0.05)$ at doses of 200,400 and $800 \mathrm{mg} / \mathrm{kg}$. The crude extract of $M$. azedarach also reduced parasitaemia to significant level on

Table 1 Yield of $80 \%$ methanol extracts of medicinal plant

\begin{tabular}{llllc}
\hline Scientific name & Sidama name & Habit & Part used & \% yield \\
\hline Ajuga integrifolia & Anamuro & Herb & Aerial & 30.0 \\
Clerodendrum myricoides & Madisisa & Herb & Leaf & 20.0 \\
Melia azedarach & Mime & Tree & Twig & 24.7 \\
Peponium vogelii & Surupa & Climber & Leaf & 27.3 \\
Premna schimperi & Udo & Shrub & Leaf & 18.0 \\
\hline
\end{tabular}

day $4(p<0.05)$ at doses of 400 and $800 \mathrm{mg} / \mathrm{kg}$. In addition, extract of $C$. myricoides reduced parasitaemia significantly on day 4 only at dose of $800 \mathrm{mg} / \mathrm{kg}(p<$ 0.05). Parasite reduction induced by extracts of $P$. schimperi and $P$. vogelii was not significant $(P>0.05)$ at all the three doses.

\section{Determination of mean survival time of extract treated mice}

Result of the survival time of mice treated with different doses of the $80 \%$ methanol extract (Table 3) indicated that treated mice survived for more days than the respective negative control groups. Moreover, the highest survival time was recorded in mice that received the highest dose of extracts. Among extracttreated mice, those treated with $800 \mathrm{mg} / \mathrm{kg} /$ day of crude extract of $A$. integrifolia survived for longer time with mean survival time of $12.00 \pm 0.44$. Mice that were treated with crude extract of $P$. schimperi survived for shorter time with mean survival days $(7.4 \pm 0.24)$ at oral dose of $200 \mathrm{mg} / \mathrm{kg} /$ day.

Comparison of the mean survival time of each test group with the respective negative controls at different dose level indicated that the crude extracts of $A$. integrifolia and $M$. azedarach prolonged the mean survival time of mice significantly $(P<0.05)$ at doses of 200,400 and $800 \mathrm{mg} / \mathrm{kg} /$ day. Extract of $C$. myricoides prolonged the survival time of mice significantly $(P<0.05)$ at doses of 400 and $800 \mathrm{mg} / \mathrm{kg} /$ day. Extracts of $P$. schimperi and $P$. vogelii prolonged the survival time of mice significantly $(P<0.05)$ only at the highest dose of $800 \mathrm{mg} / \mathrm{kg}$.

\section{Determination of mean weight of extract treated mice}

In general, the mean weight of mice that received $80 \%$ methanol extracts (Table 4 ) increased on day 4 post infection as compared to that of mice on day 0 . The weight of mice increased dose dependently. Mice that were given the highest dose showed more weight increment than mice that received the lowest dose. The highest percentage of weight change value was recorded for mice treated with $800 \mathrm{mg} / \mathrm{kg} /$ day of $A$. integrifolia extract $(10.58 \pm 0.68)$. While the least was recorded for mice that received $200 \mathrm{mg} / \mathrm{kg} /$ day of crude extracts of $P$. schimperi $(2.10 \pm 0.24)$.

Moreover, the comparison of mean weight of extract treated mice to respective controls at each dose level indicated that extracts of $A$. integrifolia, $C$. myricoides and $M$. azedarach prevented weight loss significantly $(P<$ 0.05 ) at dose of 200, 400 and $800 \mathrm{mg} / \mathrm{kg}$. Wheareas, the weight loss prevention of mice treated with extracts of $P$. schimperi and $P$. vogelii was not significant $(P>0.05)$ at $200 \mathrm{mg} / \mathrm{kg}$ but significant $(P<0.05)$ at 400 and $800 \mathrm{mg} / \mathrm{kg}$ as compared to the respective negative control of mice treated with distilled water. 
Table 2 Effect of $80 \%$ methanol crude extract of medicinal plants on parasitaemia level of $P$. berghei infected Swiss albino mice

\begin{tabular}{|c|c|c|c|c|}
\hline \multirow[t]{2}{*}{ Medicinal plant } & \multirow{2}{*}{$\begin{array}{l}\text { Dose } \\
\mathrm{mg} / \mathrm{kg} / \text { day }\end{array}$} & \multicolumn{2}{|l|}{ D4 post-infection } & \multirow[t]{2}{*}{$P$ value } \\
\hline & & $\%$ parasitaemia $(\mathrm{M} \pm \mathrm{SEM}) \mathrm{D} 4$ & \% suppression (M \pm SEM) & \\
\hline \multirow[t]{3}{*}{ Ajuga integrifolia } & 200 & $42.56 \pm 1.80^{* a}$ & $21.06 \pm 1.27$ & 0.000 \\
\hline & 400 & $40.49 \pm 1.40^{* a}$ & $24.87 \pm 1.54$ & 0.000 \\
\hline & 800 & $34.92 \pm 1.20^{* a}$ & $35.17 \pm 1.95$ & 0.000 \\
\hline \multirow[t]{3}{*}{ Clerodendrum myricoides } & 200 & $52.19 \pm 1.13$ & $3.88 \pm 1.36$ & 0.851 \\
\hline & 400 & $49.95 \pm 1.60$ & $7.18 \pm 1.94$ & 0.166 \\
\hline & 800 & $45.78 \pm 1.49^{* a}$ & $14.99 \pm 2.02$ & 0.001 \\
\hline \multirow[t]{3}{*}{ Melia azedarach } & 200 & $50.96 \pm 1.50$ & $5.43 \pm 1.50$ & 0.462 \\
\hline & 400 & $42.95 \pm 1.60^{* a}$ & $21.75 \pm 1.31$ & 0.000 \\
\hline & 800 & $36.84 \pm 1.22^{* a}$ & $31.54 \pm 2.18$ & 0.000 \\
\hline \multirow[t]{3}{*}{ Peponium vogelii } & 200 & $54.48 \pm 1.06$ & $2.62 \pm 0.89$ & 0.789 \\
\hline & 400 & $53.23 \pm 0.89$ & $5.54 \pm 0.60$ & 0.337 \\
\hline & 800 & $51.99 \pm 0.85$ & $7.20 \pm 0.77$ & 0.074 \\
\hline \multirow[t]{3}{*}{ Premna schimperi } & 200 & $56.70 \pm 0.83$ & $2.27 \pm 0.70$ & 0.933 \\
\hline & 400 & $55.90 \pm 0.64$ & $2.63 \pm 0.31$ & 0.486 \\
\hline & 800 & $54.78 \pm 0.65$ & $4.56 \pm 0.58$ & 0.066 \\
\hline NC & 0 & $53.84 \pm 0.83$ & $0.00 \pm 0.00$ & \\
\hline$P C$ & 10 & $0.00 \pm 0.0$ & $100 \pm 0.00$ & \\
\hline
\end{tabular}

Values are expressed as $\mathrm{M} \pm \mathrm{SEM} ; n=5$

$N C$ negative control $\left(0.2 \mathrm{~mL}\right.$ of $\left.\mathrm{dH}_{2} \mathrm{O}\right) ; P C$ positive control (chloroquine), $D 4$ day four

${ }^{*} P<0.05$

${ }^{a}$ compared to negative control

Table 3 Effect of $80 \%$ methanol crude extracts of medicinal plants on mean survival time of P. berghei infected Swiss albino mice

\begin{tabular}{|c|c|c|c|}
\hline Medicinal plant & Dose mg.kg/day & Mean survival time $(\mathrm{M} \pm \mathrm{SEM})$ & $P$ value \\
\hline \multirow[t]{3}{*}{ A. integrifolia } & 200 & $9.40 \pm 0.24^{* a}$ & 0.000 \\
\hline & 400 & $9.80 \pm 0.38^{* a}$ & 0.000 \\
\hline & 800 & $12.00 \pm 0.44^{* a}$ & 0.000 \\
\hline \multirow[t]{3}{*}{ C. myricoides } & 200 & $8.20 \pm 0.20$ & 0.141 \\
\hline & 400 & $9.00 \pm 0.31^{* a}$ & 0.015 \\
\hline & 800 & $10.00 \pm 0.39^{* a}$ & 0.002 \\
\hline \multirow[t]{3}{*}{ M. azedarach } & 200 & $8.60 \pm 0.24^{* a}$ & 0.032 \\
\hline & 400 & $9.30 \pm 0.37^{* a}$ & 0.011 \\
\hline & 800 & $10.90 \pm 0.58^{* a}$ & 0.001 \\
\hline \multirow[t]{3}{*}{ P. vogelii } & 200 & $7.80 \pm 0.20$ & 0.454 \\
\hline & 400 & $8.20 \pm 0.24$ & 0.227 \\
\hline & 800 & $9.20 \pm 0.37^{* a}$ & 0.017 \\
\hline \multirow[t]{3}{*}{ P. schimperi } & 200 & $7.40 \pm 0.24$ & 0.307 \\
\hline & 400 & $8.00 \pm 0.31$ & 0.084 \\
\hline & 800 & $9.40 \pm 0.50^{* a}$ & 0.030 \\
\hline NC & 0 & $6.40 \pm 0.24$ & \\
\hline PC & 10 & $30.00 \pm 0.00$ & \\
\hline
\end{tabular}

Values are expressed as $\mathrm{M} \pm \mathrm{SEM} ; n=5$

$N C$ negative control $\left(0.2 \mathrm{~mL}\right.$ of $\left.\mathrm{dH}_{2} \mathrm{O}\right), P C$ positive control (Chloroquine)

${ }^{*}=P<0.05$

$\mathrm{a}=$ compared to negative control 
Table 4 Effect of $80 \%$ methanol crude extracts of medicinal plants on body weight of $P$. berghei infected Swiss albino mice

\begin{tabular}{|c|c|c|c|c|c|}
\hline \multirow{2}{*}{$\begin{array}{l}\text { Medicinal } \\
\text { plant }\end{array}$} & \multirow{2}{*}{$\begin{array}{l}\text { Dose } \\
\mathrm{mg} / \mathrm{kg} / \text { day }\end{array}$} & \multicolumn{2}{|c|}{ Body weight $(\mathrm{M} \pm \mathrm{SEM})$} & \multirow{2}{*}{$\begin{array}{l}\% \text { of } \\
\text { change } \\
(\mathrm{M} \pm \\
\mathrm{SEM})\end{array}$} & \multirow[t]{2}{*}{$P$ value } \\
\hline & & Pre (D0) & Post (D4) & & \\
\hline \multirow[t]{3}{*}{ A. integrifolia } & 200 & $29.52 \pm 0.29$ & $31.30 \pm 0.44$ & $\begin{array}{l}6.01 \pm \\
0.51^{* a}\end{array}$ & 0.000 \\
\hline & 400 & $27.60 \pm 0.14$ & $29.08 \pm 0.32$ & $\begin{array}{l}8.56 \pm \\
0.83^{* a}\end{array}$ & 0.000 \\
\hline & 800 & $26.86 \pm 0.28$ & $29.76 \pm 0.51$ & $\begin{array}{l}10.58 \pm \\
0.68^{* a}\end{array}$ & 0.000 \\
\hline \multirow[t]{3}{*}{ C. myricoides } & 200 & $26.06 \pm 0.21$ & $27.34 \pm 0.12$ & $\begin{array}{l}4.18 \pm \\
0.60^{* a}\end{array}$ & 0.006 \\
\hline & 400 & $28.82 \pm 0.28$ & $30.20 \pm 0.14$ & $\begin{array}{l}5.84 \pm \\
0.75^{* a}\end{array}$ & 0.000 \\
\hline & 800 & $25.94 \pm 0.15$ & $27.98 \pm 0.23$ & $\begin{array}{l}7.55 \pm \\
0.67^{* a}\end{array}$ & 0.000 \\
\hline \multirow[t]{3}{*}{ M. azedarach } & 200 & $25.56 \pm 0.11$ & $26.70 \pm 0.09$ & $\begin{array}{l}4.49 \pm \\
0.38^{* a}\end{array}$ & 0.000 \\
\hline & 400 & $26.78 \pm 0.18$ & $28.52 \pm 0.30$ & $\begin{array}{l}6.56 \pm \\
0.63^{* a}\end{array}$ & 0.000 \\
\hline & 800 & $28.98 \pm 0.26$ & $31.32 \pm 0.59$ & $\begin{array}{l}8.78 \pm \\
0.89^{* a}\end{array}$ & 0.000 \\
\hline \multirow[t]{3}{*}{ P. vogelii } & 200 & $26.64 \pm 0.18$ & $27.52 \pm 0.23$ & $\begin{array}{l}2.29 \pm \\
0.39\end{array}$ & 0.062 \\
\hline & 400 & $28.60 \pm 0.31$ & $29.88 \pm 0.30$ & $\begin{array}{l}4.48 \pm \\
0.32^{*} \text { a }\end{array}$ & 0.037 \\
\hline & 800 & $28.18 \pm 0.31$ & $30.02 \pm 0.54$ & $\begin{array}{l}6.52 \pm \\
0.95^{*} \text { a }\end{array}$ & 0.008 \\
\hline \multirow[t]{3}{*}{ P. schimperi } & 200 & $26.70 \pm 0.41$ & $27.46 \pm 0.48$ & $\begin{array}{l}2.1 \pm \\
0.24\end{array}$ & 0.065 \\
\hline & 400 & $29.24 \pm 0.25$ & $30.14 \pm 0.15$ & $\begin{array}{l}4.0 \pm \\
0.31^{*}{ }^{* a}\end{array}$ & 0.031 \\
\hline & 800 & $29.38 \pm 0.28$ & $31.10 \pm 0.33$ & $\begin{array}{l}5.4 \pm \\
0.50^{* a}\end{array}$ & 0.042 \\
\hline NC & 0 & $25.56 \pm 0.24$ & $24.10 \pm 0.36$ & $\begin{array}{l}-5.56 \pm \\
0.72\end{array}$ & \\
\hline PC & 10 & $26.52 \pm 0.50$ & $29.56 \pm 0.49$ & $\begin{array}{l}10.73 \pm \\
0.50\end{array}$ & \\
\hline
\end{tabular}

Values are expressed as $\mathrm{M} \pm \mathrm{SEM} ; n=5$

$N C$ negative control $\left(0.2 \mathrm{~mL}\right.$ of $\left.\mathrm{dH}_{2} \mathrm{O}\right), P C$ positive control (Chloroquine), D4 day four

${ }^{*} P<0.05$

${ }^{a}$ compared to negative control

A paired sample $t$-test comparison between day 0 (pre treatment) and day 4 (post treatment) indicated that weight increment of mice treated with extracts of A. integrifolia and $M$. azedarach was statistically significant $(P<0.05)$ at doses of 200,400 and $800 \mathrm{mg} /$ $\mathrm{kg} /$ day on day 4 . In mice treated with extract of $C$. myricoides, the body weight increment of mice was significant $(P<0.05)$ at doses of 400 and $800 \mathrm{mg} / \mathrm{kg}$. While in mice treated with extracts of $P$ schimperi and $P$. vogelii, the weight increased significantly $(P<$ 0.05 ) only at a dose of $800 \mathrm{mg} / \mathrm{kg} /$ day.

\section{Determination of mean packed cell volume of extract} treated mice

The mean value of the packed cell volume (PCV) showed reduction in mice treated with extract (Fig. 1) and in those that were treated with the vehicle on D4 (post treatment) as compared to D0 (pre treatment). However, result of comparison between D0 and D4 of extract treated mice with the respective negative control groups showed no appreciable reduction.

The comparison of PCV change of extracts treated mice at different dose levels with the respective negative controls treated with the vehicle indicated that the PCV value of mice treated with crude extracts of $A$. integrifolia and $M$. azedarach deviated significantly from the negative controls $(P<0.05)$ at doses of 200,400 and $800 \mathrm{mg} / \mathrm{kg} /$ day. The deviation of PCV value of mice treated with extract of $C$. myricoides was significant $(P<$ 0.05 ) at doses of 400 and $800 \mathrm{mg} / \mathrm{kg} /$ day. Whereas, in the case of mice treated with extracts of $P$. schimperi and $P$. vogelii, the deviation was significant $(P<0.05)$ only at the highest dose $(800 \mathrm{mg} / \mathrm{kg})$. The paired sample $t$-test result between D0 and D4 of mice treated with extracts at doses of 200, 400 and $800 \mathrm{mg} / \mathrm{kg} /$ day indicated significant decrease $(P<0.05)$ of $\mathrm{PCV}$ value on $\mathrm{D} 4$.

\section{Percentage yield of fractions of Ajuga integrifolia}

The highest percentage of yield was obtained from $\mathrm{n}$ butanol fraction (35.0\%) of the aerial part of $A$. integrifolia, followed by that of water $(24.7 \%)$ and chloroform $(17.0 \%)$. There was also variation in the physical appearance of the fractions. The water fraction was sticky and solid while that of n-butanol and chloroform fractions were jelly.

\section{Phytochemical tests on extract of Ajuga integrifolia}

Result of phytochemical screening tests on the extract of A. integrifolia revealed the presence or absence of main secondary metabolites and other phytochemicals based on presence or absence of expected colour changes (Table 5). The methanol extract of A. integrifolia contained alkaloids, terpenoids, flavonoids, steroids, saponins, tannins, anthraquinone, phenols and fats and oils.

In vivo antimalarial tests of fractions of Ajuga integrifolia

Result of the four-day suppressive test of the three fractions at different dose levels on parasitaemia level of mice infected with $P$. berghei is summarized in Table 6 . The result is expressed as the percent of reduction of parasitaemia in reference to the negative control mice treated with the vehicle. As the result indicated, the three fractions exhibited antiplasmodial activity in vivo against $P$. berghei. The fractions reduced parasitaemia to different levels in dose-dependant manner. The highest inhibition of parasitaemia was exhibited by n-butanol 


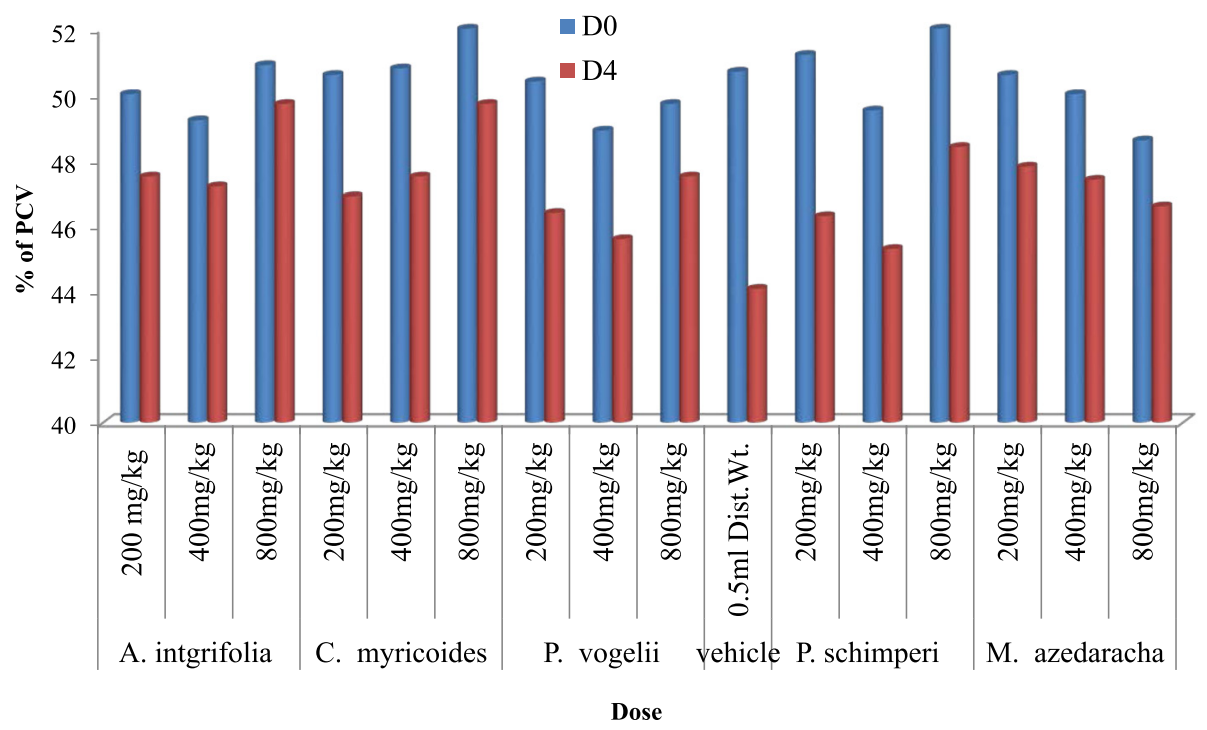

Fig. 1 Effect of $80 \%$ methanol crude extracts of medicinal plants on PCV of $P$. berghei infected Swiss albino mice. Keys: Vehicle $(N C)=$ negative control; D0 = day 0; D4 = day 4; PCV = Packed Cell Volume; $(n=5)$

fraction $(29.80 \pm 0.66)$ at $400 \mathrm{mg} / \mathrm{kg} /$ day and the lowest by chloroform fraction $(3.68 \pm 0.83)$ at $100 \mathrm{mg} / \mathrm{kg} /$ day. The comparison of the test groups to their respective negative controls indicated that the n-butanol fraction reduced parasitaemia to significant level on day 4 ( $p<$ $0.05)$ at the doses of 100,200 and $400 \mathrm{mg} / \mathrm{kg} /$ day. Water fraction reduced parasitaemia to significant level $(p<$ $0.05)$ at doses of 200 and $400 \mathrm{mg} / \mathrm{kg} /$ day. Parasite reduction of chloroform fractions was not significant $(p>$ $0.05)$ at all the three doses.

Although the extracts and fractions reduced parasite load in treated group of mice, none of the crude extracts or fractions completely cleared the parasite. In the positive control group of mice treated with standard antimalarial drug chloroquine phosphate, at daily dose of
$10 \mathrm{mg} / \mathrm{kg}$ body weight, the parasite was totally cleared on day four-post infection.

\section{Determination of mean survival time of fraction treated mice}

Result of the mean survival time of mice treated with different doses of the fractions of $A$. integrifolia (Fig. 2) indicated that treated mice survived for more days as compared with those in the negative control group with the highest survival time recorded for mice that received the highest dose of n-butanol fraction $(400 \mathrm{mg} / \mathrm{kg} /$ day). Comparison of the mean survival time of fraction treated mice to the negative controls at different dose levels showed that the mean survival time of mice that were treated with $\mathrm{n}$-butanol fraction was prolonged

Table 5 Phytochemical constituents of $80 \%$ methanol extract of A. integrifolia

\begin{tabular}{lll}
\hline Test & Reagents & Test result \\
\hline Alkaloid & Wagner's reagent & ++ \\
Terpenoids & Chloroform, acetic anhydride, concentrated sulphuric acid & ++ \\
Flavonoids & Magnesium ribbon, concentrated hydrochloric acid & ++ \\
Steroids & Chloroform, concentrated H2SO4 & + \\
Tannin & $10 \%$ ferric chloride $(\mathrm{FeCl})_{3}$ & + \\
Saponins & distilled water & + \\
Anthraquinone & $\mathrm{KOH}$ & + \\
Phenol & ferric chloride & + \\
Proteins & Millions reagent & - \\
Carbohydrate & Fehling solution, $\mathrm{HCl}, \mathrm{NaOH}$ & + \\
Fats and oils & Filter paper & + \\
\hline
\end{tabular}

$+++=$ very strong positive,$++=$ strong positive, $+=$ fair positive, ${ }^{-}=$absent 
Table 6 Antimalarial activity of solvent fractions of A. integrifolia on parasitaemia level of $P$. berghei infected Swiss albino mice

\begin{tabular}{|c|c|c|c|c|}
\hline \multirow{2}{*}{$\begin{array}{l}\text { Fraction } \\
\text { type }\end{array}$} & \multirow{2}{*}{$\begin{array}{l}\text { Dose } \\
\mathrm{mg} / \mathrm{kg} / \text { day }\end{array}$} & \multicolumn{2}{|l|}{ D4 post infection } & \multirow[t]{2}{*}{$P$ value } \\
\hline & & $\%$ of Parasitaemia $(\mathrm{M} \pm \mathrm{SEM})$ & $\%$ of inhibition $(\mathrm{M} \pm \mathrm{SEM})$ & \\
\hline \multirow[t]{3}{*}{ Water } & 100 & $43.20 \pm 1.65$ & $9.72 \pm 1.27$ & 0.091 \\
\hline & 200 & $42.40 \pm 1.50^{* a}$ & $11.29 \pm 1.01$ & 0.035 \\
\hline & 400 & $36.60 \pm 1.21^{* a}$ & $23.44 \pm 1.10$ & 0.001 \\
\hline \multirow[t]{3}{*}{ n-Butanol } & 100 & $42.20 \pm 1.06^{* a}$ & $11.80 \pm 2.09$ & 0.026 \\
\hline & 200 & $39.80 \pm 1.28^{* a}$ & $17.16 \pm 0.94$ & 0.014 \\
\hline & 400 & $35.80 \pm 1.28^{* a}$ & $29.80 \pm 0.66$ & 0.000 \\
\hline \multirow[t]{3}{*}{ Chloroform } & 100 & $47.00 \pm 1.41$ & $3.68 \pm 0.83$ & 0.752 \\
\hline & 200 & $46.20 \pm 1.49$ & $5.78 \pm 11.69$ & 0.494 \\
\hline & 400 & $47.80 \pm 1.39$ & $9.80 \pm 3.41$ & 0.157 \\
\hline NC & 0 & $49.20 \pm 1.50$ & $0.00 \pm 0.00$ & \\
\hline PC & 10 & $0.00 \pm 0.00$ & $100.00 \pm 0.00$ & \\
\hline
\end{tabular}

Values are expressed as $\mathrm{M} \pm \mathrm{SEM} ; n=5$

NC negative control $(0.2 \mathrm{~mL}$ of $\mathrm{dH} 2 \mathrm{O}), P C$ positive control (Chloroquine), $D 4$ day four $* P<0.05$

${ }^{\mathrm{a}}$ compared to negative control

significantly $(P<0.05)$ at doses of 100,200 and $400 \mathrm{mg} /$ $\mathrm{kg} /$ day. Water fraction prolonged the survival time of mice significantly $(P<0.05)$ at doses of 200 and $400 \mathrm{mg} /$ $\mathrm{kg} /$ day. While, chloroform fraction prolonged the mean survival time of mice significantly $(P<0.05)$ at oral dose of $400 \mathrm{mg} / \mathrm{kg} /$ day.

\section{Determination of mean weight of fraction treated mice}

In general, the mean weight of mice that received fractions of A. intefrifolia (Table 7) increased on day 4 post infection as compared to that of day 0 . The weight of mice increased dose dependently. Mice that were given the highest dose showed more increment than mice that received the lowest dose. Among treated groups, the highest weight change $(9.40 \pm 0.58)$ was recorded for mice treated with $400 \mathrm{mg} / \mathrm{kg} /$ day of $\mathrm{n}$-butanol fraction

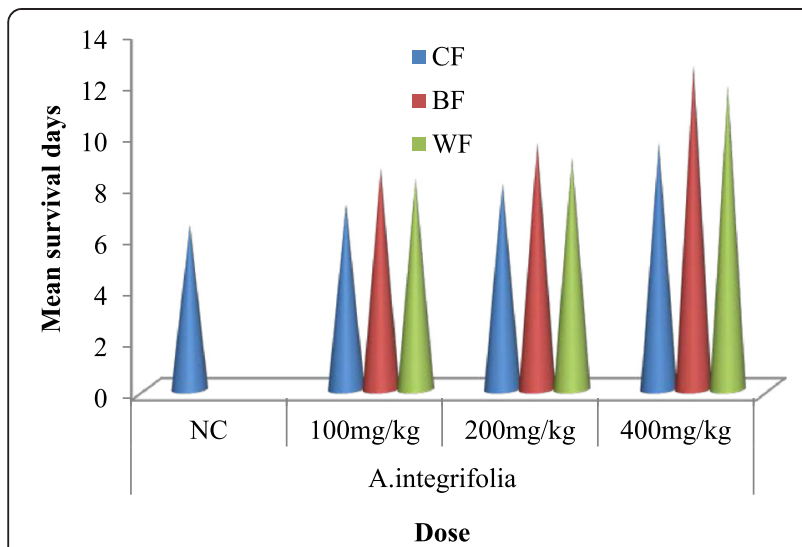

Fig. 2 Effect of butanol, water and chloroform fractions of $A$. integrifolia on mean survival time of $P$. berghei infected Swiss albino mice. $(n=5)$. Keys: $\mathrm{BF}=$ butanol fraction; $\mathrm{WF}=$ water fraction; $\mathrm{CF}=$ chloroform fraction; $\mathrm{NC}=$ negative control
Table 7 Effect of water, butanol and chloroform fractions on body weight of $P$. berghei infected Swiss albino mice

\begin{tabular}{|c|c|c|c|c|c|}
\hline \multirow{2}{*}{$\begin{array}{l}\text { Fraction } \\
\text { type }\end{array}$} & \multirow{2}{*}{$\begin{array}{l}\text { Dose } \\
\mathrm{mg} / \mathrm{kg} / \text { day }\end{array}$} & \multicolumn{2}{|c|}{ Body weight $(\mathrm{M} \pm \mathrm{SEM})$} & \multirow{2}{*}{$\begin{array}{l}\% \text { of } \\
\text { change } \\
(\mathrm{M} \pm \mathrm{SEM})\end{array}$} & \multirow[t]{2}{*}{$P$ value } \\
\hline & & $\mathrm{DO}$ & D4 & & \\
\hline \multirow[t]{3}{*}{ Water } & 100 & $26.20 \pm 0.44$ & $27.06 \pm 0.46$ & $\begin{array}{l}3.28 \pm \\
0.24^{* a}\end{array}$ & 0.027 \\
\hline & 200 & $28.14 \pm 0.39$ & $29.82 \pm 0.48$ & $\begin{array}{l}6.10 \pm \\
0.30^{* a}\end{array}$ & 0.018 \\
\hline & 400 & $28.80 \pm 0.17$ & $31.28 \pm 0.13$ & $\begin{array}{l}9.03 \pm \\
0.32^{* a}\end{array}$ & 0.000 \\
\hline \multirow[t]{3}{*}{ n-Butanol } & 100 & $27.64 \pm 0.09$ & $28.80 \pm 0.20$ & $\begin{array}{l}3.19 \pm \\
0.51^{* a}\end{array}$ & 0.033 \\
\hline & 200 & $27.96 \pm 0.06$ & $29.38 \pm 0.10$ & $\begin{array}{l}6.23 \pm \\
0.48^{* a}\end{array}$ & 0.026 \\
\hline & 400 & $28.52 \pm 0.13$ & $30.40 \pm 0.21$ & $\begin{array}{l}6.59 \pm \\
0.58^{* a}\end{array}$ & 0.000 \\
\hline \multirow[t]{3}{*}{ Chloroform } & 100 & $26.34 \pm 0.25$ & $26.94 \pm 0.31$ & $\begin{array}{l}2.26 \pm \\
0.32\end{array}$ & 0.080 \\
\hline & 200 & $27.12 \pm 0.31$ & $28.04 \pm 0.39$ & $\begin{array}{l}3.67 \pm \\
0.46\end{array}$ & 0.072 \\
\hline & 400 & $29.08 \pm 0.27$ & $30.58 \pm 0.4$ & $\begin{array}{l}5.14 \pm 0 \\
.42^{* a}\end{array}$ & 0.031 \\
\hline NC & 0 & $26.80 \pm 0.33$ & $25.86 \pm 0.27$ & $\begin{array}{l}-2.41 \pm 0 \\
.92\end{array}$ & \\
\hline PC & 10 & $27.38 \pm 0.51$ & $28.94 \pm 0.62$ & $\begin{array}{l}5.00 .95 \pm \\
0.71\end{array}$ & \\
\hline
\end{tabular}

Values are expressed as $\mathrm{M} \pm \mathrm{SEM} ; n=5$

$N C$ negative control $\left(0.2 \mathrm{~mL}\right.$ of $\left.\mathrm{dH}_{2} \mathrm{O}\right), P C$ positive control (Chloroquine) ${ }^{*} P<0.05$

${ }^{\mathrm{a}}$ compared to negative control 
and the least $(2.26 \pm 0.32)$ for mice that received $100 \mathrm{mg} / \mathrm{kg}$ of chloroform fraction. Moreover, the comparison of mean weight of fraction treated mice to respective controls at each dose level indicated that n-butanol and water fractions prevented weight loss of mice significantly at 100, 200 and $400 \mathrm{mg} / \mathrm{kg} /$ day doses $(P<0.05)$. Whereas, chloroform fractions prevented weight loss significantly only at $400 \mathrm{mg} / \mathrm{kg} /$ day $(P<0.05)$ as compared to the respective negative control mice. A paired sample $t$-test comparison between D0 and D4 indicated significant $(P<0.05)$ weight increment of mice treated with $\mathrm{n}$-butanol and water fractions at dose of 100, 200 and $400 \mathrm{mg} / \mathrm{kg} /$ day.

\section{Determination of mean packed cell volume of fraction treated mice}

The mean value of the packed cell volume (PCV) showed reduction in mice treated with fractions of $A$. integrifolia and those in the negative control group on D4 as compared to D0 (Fig. 3, Fig. 4 and Fig. 5). However, result of comparison of PCV of D0 and D4 fraction treated mice with that of the respective PCV of mice in the negative control group showed no appreciable reduction. The comparative test indicated that PCV values of mice that were treated with n-butanol and water fractions deviated significantly $(P<0.05)$ at doses of 100,200 and $400 \mathrm{mg} / \mathrm{kg} /$ day from that of the mice in the negative control group. The deviation of the PCV value of mice treated with chloroform fraction from that of mice in the negative control group was significant $(P<0.05)$ only at dose of $400 \mathrm{mg} / \mathrm{kg} /$ day. The paired sample $t$-test result between D0 and D4 of mice treated with water, nbutanol and chloroform fractions at doses of 100, 200 and $400 \mathrm{mg} / \mathrm{kg} /$ day indicated that on day 4, the PCV value showed significant reduction in all test group $\operatorname{mice}(P<0.05)$.

\section{Discussion}

As findings of the acute toxicity test indicate, no gross behavioral changes such as impaired movement, reduced

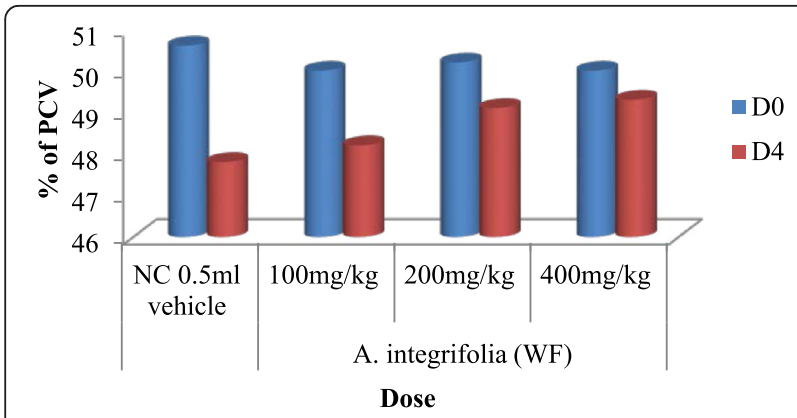

Fig. 3 Effect of water fraction of A. integrifolia on PCV of $P$. berghei infected Swiss albino mice. Keys: WF = water fraction; NC = negative control; D0 = Day 0; D4 = Day 4; PCV = Packed Cell Volume; $(n=5)$

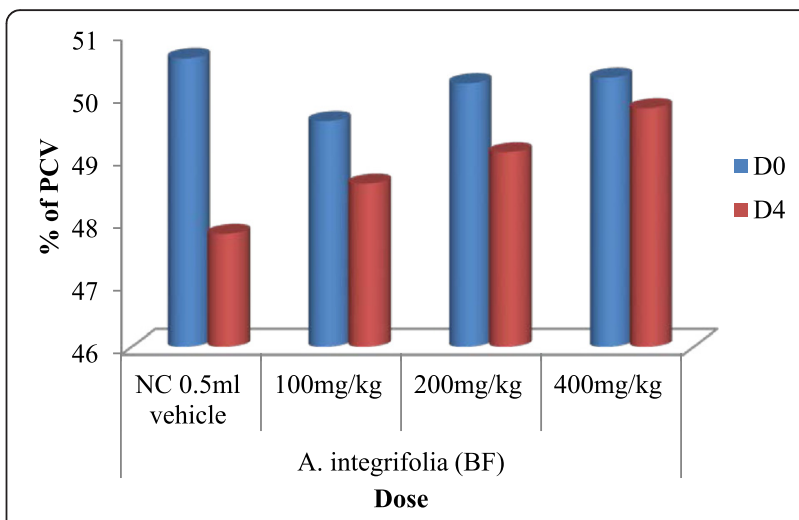

Fig. 4 Effect of butanol fraction of $A$. integrifolia on PCV of $P$. berghei infected Swiss albino mice. Keys: BF = butanol fraction; $N C=$ negative control; D0 = Day 0; D4 = Day 4; PCV = Packed Cell Volume; $(n=5)$

motor activity and mortality were manifested in mice that were treated with single dose of $2000 \mathrm{mg} / \mathrm{kg}$. The methanol extract treated mice were in the same condition as that of the control group mice that were treated with distilled water over the observation time of ten days. Thus, the extracts of the tested medicinal plants parts could be considered safe at the dose levels used in this the experiment. The result, therefore, justify the use of such plant parts by the Sidama people for the treatment of malaria. Toxicity tests carried out elsewhere on extracts of the plants Melia azedarach [28], C. myricoides [29] and Ajuga spp. [30] also showed their safety on laboratory animals at doses of $2000 \mathrm{mg} / \mathrm{kg}$ and above.

The methanol extracts of the five medicinal plants reduced the malaria parasite load in mice during the fourday suppressive test suggesting their suppressive effect on the blood stage of the parasite. Among the extracts, parasite load was decreased significantly in mice treated

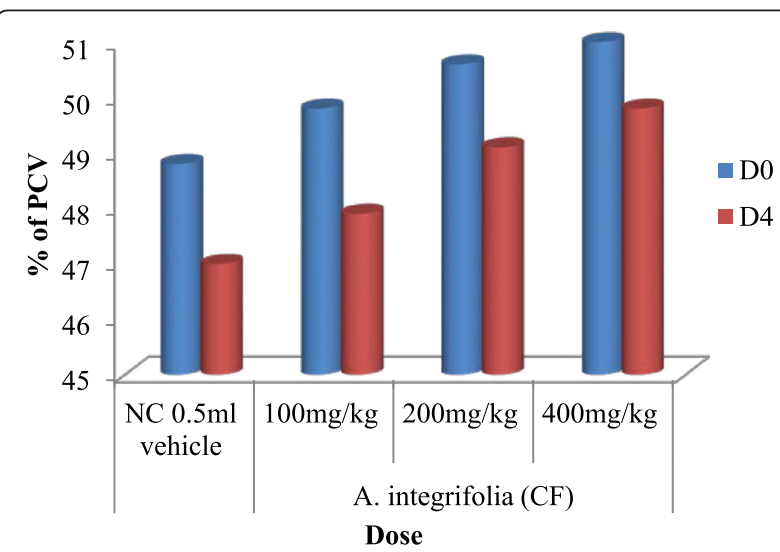

Fig. 5 Effect of chloroform fraction of $A$. integrifolia on PCV of $P$. berghei infected Swiss albino mice. Keys: CF = chloroform fraction; $\mathrm{NC}=$ negative control; $\mathrm{D0}=$ Day 0; D4 = Day 4; PCV = Packed Cell Volume; $(n=5)$ 
with extract of $A$. integrifolia at all the three doses (200, 400 and $800 \mathrm{mg} / \mathrm{kg} /$ day). The highest suppression was recorded for $A$. integrifolia at the highest test dose of $800 \mathrm{mg} / \mathrm{kg} /$ day. An investigation carried out elsewhere also indicated high level (90.4 \%) of suppression of parasitaemia in mice treated with water extract of Ajuga remota, a close relative of $A$. integrifolia, at a dose of $30 \mathrm{mg} / \mathrm{kg}$ [17]. A study by Irungu et al. [18] revealed that aqueous, methanol and dichloromethane extracts of the root bark extracts of C. myricoides exhibited antimalarial activities in vitro with $\mathrm{IC}_{50}$ values of $64 \mu \mathrm{g} / \mathrm{mL}$, $48.2 \mu \mathrm{g} / \mathrm{mL}, 15.8 \mu \mathrm{g} / \mathrm{mL}$, respectively. Bark extract of Melia azedarach was reported to show in vitro antiplasmodial activity with IC50 value of $66.2 \mu \mathrm{g} / \mathrm{mL}$ [19].

However, the extracts did not eradicate the parasite completely unlike the standard chloroquine drug. As dayto-day observation during post treatment period indicated, clinical symptoms of the infection were seen in the treated mice due to gradual increment of the parasitaemia. The subsequent development of the parasitaemia in all the extracts treated mice might suggest that the actions of the extracts were short-lived due to their rapid metabolism or elimination [31]. The limited effect also might be related to partial loss of active ingredients due to its insufficient uptake to physiologically active level [32].

Although the mechanism of action of the extracts was not explained, the reduction of parasite load in the treated mice might be due to the presence phytochemical constituents such as alkaloids, flavonoids, and terpenoids. Previous studies have indicated the potential of alkaloids, terpenoids, flavonoids, coumarins, phenolics, polyacetylenes, xanthones, quinones, steroids and lignans for antimalarial drug development [33, 34]. Ajuga remota, a related species of $A$. integrifolia, was reported to have shown antimalarial activity due to the presence of terpenoids [33]. Another report also indicated the antimalarial activity of the compounds triterpenoids and limonoids [35].

In vivo evaluation of the n-butanol, water and chloroform fractions of $A$. integrifolia indicated that the $\mathrm{n}$ butanol and water fractions of the plants suppressed parasitaemia to a significant level at all the three doses (100, 200 and $400 \mathrm{mg} / \mathrm{kg} /$ day). The relatively high antimalarial action of the n-butanol fraction could be the result of a single or synergistic effect of the secondary metabolites such as alkaloids, saponins, flavonoids, tannins and phenols found in the fraction [36]. The result of the present study is in agreement with findings documented by Yared et al. [37] and Mengiste et al. [38], where n-butanol fraction of $A$. africanus and $D$. angustifolia significantly suppressed parasitaemia in treated mice. The water fraction also reduced parasitaemia dose dependently but the level of activity was less as compared to that of n-butanol, indicating the difference in the type and concentration of the different secondary metabolites in the fractions [39]. The insignificant parasitaemia reduction by chloroform fraction may be due to less concentration of secondary metabolites available in the extract.

Comparison of the activity of the crude extract of $A$. integrifolia with that of its fractions showed that the fractions (n-butanol, water and chloroform) demonstrated less antiplasmodial activity. The relatively higher potency of the crude extract may be attributed to the presence of various phytochemical constituents that work singly or synergistically, but might be reduced or lost during fractionation. Some secondary metabolites protect other metabolites (as antioxidants) and breaking of this association could accelerate degradation and consequently reduction of the suppressive effect of the ingredients [40]. Similar finding was reported indicating greater chemossuppression induced by water extracts of Ageratum conyzoides as compared to that of methanol, water and chloroform [41]. Eighty percent methanol leaf extract of Otostegia integrifolia also showed to have high antimalarial activity than its respective ethanol, water and chloroform fractions [42].

Treatment with the plants crude extracts and fraction extended survival time of mice in the treatment groups as compared with the mice in non-treated control groups. The survival time of the extract and fraction treated mice for more days in the presence of the parasite might be due to the phytochemical ingredients, which have antioxidant property that reduce the overall pathologic effect of the parasite and prolong the survival time of mice as compared to those in the negative control group. Phytochemical constituents such as flavonoids and tannins have been suggested to act as primary antioxidant or free radical scavengers that aid antioxidant defense system and reduce oxidative stress that is induced by the malaria parasite [43].

Body weight loss is one of the features observed in rodents infected with malaria parasite due to poor appetite that develops because of the intensity of the infection [44]. During the period of 4-day suppressive test, the extracts and fractions protected mice from losing weight. The weight of the negative control mice decrease tremendously where as the weight of crude extracts and fractions treated mice increased gradually. The weight increment in treated mice might be due to the extracts or fractions pharmacological effect that counteract other aspects of malaria illness such as fever, immunosuppression and pain. Mice treated with extracts of A. integrifolia, C. myricoides, $M$. azedarach and $P$. vogelii significantly prevented weight loss in dose dependant fashion. Our finding was consistent with other studies [45-47] where mice treated with extracts of different plants showed weight increment dose dependently. 
Malaria-caused anemia occurs due to hemolysis of red blood cells because of destruction of infected and uninfected red blood cells as well as erythropoietic suppression and dyserythropoiesis [48]. The PCVs of malaria-infected mice that were treated with the extracts and fractions were reduced on the 4th day of post infection. The reduction of PCV in the treated mice might be related to the different phytochemical components present in tested plants. Some studies indicated that saponins are known to cause hemolysis by increasing the permeability of plasma membrane of the red blood cells [49]. The methanol extracts and fractions prevented a drastic reduction in PCV in infected mice as compared with that in the negative control. This shows the role of the extracts and fractions in preventing radical anemic conditions that were manifested in mice in negative control due to severe infection. This could be due to the marked decrease in parasite load in the course of infection in mice treated with the extracts and fractions in dose dependant manner. In the untreated mice, the parasite number increased and consequently destroyed more red blood cells and so resulted in marked decrease of hematocrit PCV.

\section{Conclusions}

Acute toxicity test result of methanol crude extracts of the tested plants showed no sign of toxicity in mice treated up to a dose of $2000 \mathrm{mg} / \mathrm{kg}$, supporting their traditional use. In vivo antimalarial test results indicated that crude extracts and fractions of the plant materials showed potent antimalarial activity in dose dependant fashion. Especially, the crude extract and n-butanol and water fractions of $A$. integrifolia showed significant chemosuppression, justifying the local use of the plants to treat malaria. Further in vivo and in vitro investigations are recommended to evaluate, in detail, the antiplasmodial activity and safety of the plants.

\section{Ethical consideration}

The proposal was reviewed and approved by the Institutional Review Board of Aklilu Lemma Institute of Pathobiology, Addis Ababa University. The mice were handled in accordance with national guidelines for handling laboratory animals.

\section{Availablity of data and materials}

Voucher specimens of the tested antimalarial plants were deposited at the National Herbarium of the Addis Ababa University with numbers Bor 9 for Ajuga integrifolia, BOR 32 for Clerodendrum myricoides, Bor 5 for Melia azedarach, BOR 10 for Peponium vogelii and BOR 18 for Premna schimperi. Antimalarial in vivo tests data were deposited into a computer available at Aklilu Lemma Institute of Pathobiology, Addis Ababa University.
Competing interests

The authors declare that they have no competing interests.

\section{Authors' contributions}

SA drafted the proposal and MG, T, BE and $\mathrm{AH}$ reviewed it. SA performed the experiment, analyzed and interpreted the data. All authors participated in the write-up of the manuscript. All authors have read and approved the final manuscript.

\section{Acknowledgments}

We are very grateful to the School of Graduate Studies of the Addis Ababa University (AAU) and the Aklilu Lemma Institute of Pathobiology of AAU for providing materials and financial support. We also thank Medicine and Health Science College, Hawassa University, for additional financial support. Our sincere appreciation goes to some staff of the Drug Research Department, the Ethiopian Public Health Institute, in particular, Dr. Asfaw Debela, Yared Debebe, Abye Abate, Brhanu Asyaghn and Yewhalaeshet Belete for their all-rounded assistance during laboratory work. We are delighted to extend our heartfelt thanks to Tadesse G/Giorgies and Eshetu Assefa from School of Pharmacy, AAU, for their assistance in extraction of plant samples.

\section{Author details}

${ }^{1}$ Medicine and Health Science College, Hawassa University, P.O. Box 1560, Hawassa, Ethiopia. ${ }^{2}$ Aklilu Lemma Institute of Pathobiology, Addis Ababa University, P.O. Box 1176, Addis Ababa, Ethiopia. ${ }^{3}$ School of Pharmacy, Addis Ababa University, P.O. Box 1176, Addis Ababa, Ethiopia.

Received: 24 September 2015 Accepted: 16 December 2015 Published online: 23 December 2015

\section{References}

1. WHO. World malaria fact sheet. Geneva: World Health Organization; 2013.

2. WHO. The african malaria report. Geneva: World Health Organization; 2006.

3. WHO. World Malaria Report. Geneva: World Health Organization; 2012.

4. $\mathrm{FMoH}$. Malarial diagnosis and treatment guidelines for health workers in Ethiopia. 2nd ed. Addis Ababa: Federal Ministry of Health; 2004.

5. WHO. Guidelines for the treatment of malaria. 2nd ed. Geneva: World Health Organization; 2010

6. Willcox M, Graz B, Falquet J, Diakite C, Giani S, Diallo DA. Reverse pharmacology" approach for developing an anti-malarial phytomedicine. Malar J. 2011;10(1):S8.

7. Dondorp AM, Nosten F, Yi P, Das D, Phyo AP, Taming J, et al. Artemisinin resistance in P. falciparum malaria. N Engl J Med. 2009;361:455-67.

8. Dippmann AK, Bienzle U, Harms G, Mockenhaupt FP. Pfmdr1 mutations in imported African P. falciparum isolates. Trans R Soc Trop Med Hyg. 2008:102:1148-50

9. Wongsrichanalai C, Pickard AL, Wernsdorfer WH, Meshnick SR. Epidemiology of drug-resistant malaria. Lancet Infect Dis. 2002;2:209-18.

10. Abebe D. The Role of medicinal plants in healthcare coverage of Ethiopia, the Possible Integration. In: Medhin Z, Abebe D, editors. Conservation and sustainable use of medicinal plants in ethiopia proceeding of the national workshop on biodiversity conservation and sustainable use of medicinal plants in Ethiopia. Addis Ababa: IBCR; 2001. p. 6-21.

11. Seifu T, Asres K, Gebre MT. Ethnobotanical and ethnopharmacologlcal studies on medicinal plants of Chifra Woreda, Afar Region, North Eastern Ethiopia. EPJ. 2006;24:41-58.

12. Flatie T, Gedif T, Asres K, Gebre-Mariam T. Ethnomedical survey of berta ethnic group assosa zone, benishangul-gumuz regional state, mid-west Ethiopia. J Ethnobiol Ethnomed. 2009;5:14-27.

13. Giday M, Asfaw Z, Woldu Z. Medicinal plants of Meinit ethnic group of Ethiopia. an ethnobotanical study. J Ethnopharmacol. 2009;124:513-21.

14. Giday M, Asfaw Z, Woldu Z. Ethnomedicinal study of plants used by Sheko ethnic group of Ethiopia. J Ethnopharmacol. 2010;124:513-21.

15. Mesfin A, Giday M, Animut A, Teklehaymanot T. Ethnobotanical study of antimalarial plants in Shinile Woreda, Somali Region, Ethiopia, and in vivo evaluation of selected ones against P. berghei. J Ethnopharmacol. 2012;139:221-7.

16. Trotter RT, Logan MH. Informants consensus: a new approach for identifying potentially effective medicinal plants. In: Etkin NL, editor. Plants in 
Indigenous medicine and diet. Bedford Hill: Redgrave Publishing Company; 1986. p. 91-112.

17. Gitua JN, Muchiri DR, Nguyen XT. In vivo antimalarial activity of Ajuga remota water extracts against $P$. berghei in mice. Southeast Asian J Trop Med Public Health. 2012;43:545-8.

18. Irungu BN, Rukunga GM, Mungai GM, Muthaura CN. In vitro antiplasmodial and cytotoxicity activities of 14 medicinal plants from Kenya. S Afr J Bot. 2007;73:204-7.

19. Valdes AFC, Martinez JM, Lizama RS, Gaiten YG, Rodriguez DA, Payrol JA. In vitro Antimalarial activity and cytotoxicity of some selected Cuban medicinal plants. Rev Inst Med Trop Sao Paulo. 2010;52:197-201.

20. Madureira MC, Martins AP, Gomes M, Paiva J, Cunha AP, Rosa'rio V. Antimalarial activity of medicinal plants used in traditional medicine in $\mathrm{S}$. Tome' and Pri'ncipe islands. J Ethnopharmacol. 2002;81:23-9.

21. Belay T. In vivo antimalarial activity of the root extracts and fractions of Clerodendrum myricoides in Plasmodium berghei infected mice. MSc thesis. Addis Ababa: Addis Ababa University; 2008.

22. Alshawsh MA, Mothana RA, Al-shamahy HA, Alsllami SF, Lindequis U. Assessment of antimalarial activity against Plasmodium falciparum and phytochemical screening of some Yemeni medicinal plants. Evid Based Complement Alternat Med. 2009:6:453-6.

23. Ayaz M, Junaid M, Ahmed J, Ullah F, Sadiq A, Ahmad S, et al. Phenolic contents, antioxidant and anticholinesterase potentials of crude extract, subsequent fractions and crude saponins from Polygonum hydropiper $\mathrm{L}$. BMC Complement Altern Med. 2014;14:145-54.

24. Tiwari P, Kumar B, Kaur M, Kaur G, Kaur H. Phytochemical screening and extraction: a review. IPS. 2011;1:98-106.

25. Murithi CK, Fidahusein DS, Nguta JM, Lukhoba CW. Antimalarial activity and in vivo toxicity of selected medicinal plants naturalised in Kenya. Int J Edu Res. 2014:2:395-406.

26. Peters $W$, Portus $H$, Robinson $L$. The four-day suppressive in vivo antimalarial test. Ann Trop Med Parasit. 1995;69:155-71.

27. Kalra BS, Chawla S, Gupta P, Valecha N. Screening of antimalarial drugs. Indian J Pharmacol. 2006:38:5-12

28. Rahman A, Qureshi S, Ranman AU, Badar Y. Toxicological studies of Melia azedarach (flowers and berries). Pak J Pharm Sci. 1991:4:153-8.

29. Deressa T, Mekonnen Y, Animut A. In Vivo anti-malarial activities of Clerodendrum myricoides, Dodonea angustifolia and Aloe debrana against Plasmodium berghei. EJHD. 2010;24:25-9.

30. Chandel S, Bagai U. Antiplasmodial activity of Ajuga bracteosa against Plasmodium berghei infected BALB/c mice. Indian J Med Res. 2010;131:440-60.

31. Waako PJ, Gumede B, Smith P, Folb PI. The in vitro and in vivo antimalarial activity of Cardiospermum halicacabum and Momordica foetida. J Ethnopharmacol. 2005;99:137-43.

32. Nok AJ. Effective measures for controlling trypanosomiasis. Expert Opin Pharmacother. 2005;6:2645-53.

33. Onguéné PA, Ntie-Kang F, Lifongo LL, Ndom JC, Sippl W, Mbaze LM. The potential of anti-malarial compounds derived from African medicinal plants. Part l: A pharmacological evaluation of alkaloids and terpenoids Malar J. 2013;12:449

34. Ntie-Kang F, Onquén PA, Lifongo LL, Ndom JC, Sippl W, Mbaze LM. The potential of anti-malarial compounds derived from African medicinal plants, part II: a pharmacological evaluation of non-alkaloids and non-terpenoids. Malar J. 2014;13:81.

35. Azam MM, Mamunor RA, Towfique NM, Sen MKL, Nasrin S. Pharmacological potentials of Melia azedarach L. AJBIO. 2013;1:44-9.

36. Tanko Y, Mabrouk MA, Adelaiye AB, Fatihu MY, Musa KY. Anti-diabetic and some haematological effects of ethylacetate and $n$-butanol fractions of Indigofera pulchra extract on alloxan-induced diabetic Wistar rats. J Diabetes Endocrinol. 2011;2:1-7.

37. Yared D, Mekonnen Y, Debella A. In vivo antimalarial activities of fractionated extracts of Asparagus africanus in mice infected with Plasmodium berghei. Pharmacologyonline. 2012;3:88-94.

38. Mengiste B, Makonnen E, Urga K. In vivo antimalarial activity of Dodonaea Angustifolia Seed Extracts Against $P$. berghei in mice model. Momona Ethiop J Sci. 2012:4:47-63.

39. Amelo W, Nagpal P, Makonnen E. Antiplasmodial activity of solvent fractions of methanolic root extract of Dodonaea angustifolia in Plasmodium berghei infected mice. BMC Complement Altern Med. 2014;14:462-9.

40. Traore M, Guiguemde A, Yago I, Nikièma JB, Tinto H, Dakuyo ZP, et al. Investigation of antiplasmodial compounds from two plants,
Cochlospermum tinctorium a. rich and Gardenia sokotensis hutch. Afr J Tradit Complement Altern Med. 2006:3:34-41.

41. Ukwe VC, Epueke EA, Ekwunife Ol, Okoye TC, Akudor GC, Ubaka CM. Antimalarial activity of aqueous extract and fractions of leaves of Ageratum conyzoides in mice infected with Plasmodium berghei. Int J Pharm Pharm Sci. 2010;2:33-8.

42. Endale A, Bisrat D, Animut A, Bucar F, Asres K. In vivo Antimalarial Activity of a Labdane Diterpenoid from the Leaves of Otostegia integrifolia Benth. Phytother Res. 2013;10:1-5.

43. Okokon JE, Ita BN, Udokpoh AE. The In vivo anti malarial activities of Uvaria chamae and Hippocratea africana. Ann Trop Med Parasit. 2006;100:585-90.

44. Yen WJ. Possible anti-obesity therapeutics from nature a review. Phytochem. 2010:71:1625-41.

45. Dikasso D, Makonnen E, Debella A, Animut A, Urga K, Makonnen W, et al. Antimalarial activity of Withania somnifera L. Dunal in mice Ethiop Med J. 2006;44:279-85

46. Oluwakanyinsola AS, Tijani AY, Babayi H, Nwaeze AC, Anagbogu RA, Agbakwuru VA. Anti-malarial activity of ethanolic stem bark extract of Faidherbia Albida (Del) a. Chev (Mimosoidae) in mice. Arch Appl Sci Res. 2010;2:261-8.

47. Bantie LM. In vivo antimalarial activity of the crude root and fruit extracts of Croton macrostachyus (Euphorbiaceae) against Plasmodium berghei in mice. Journal of Traditional and Complementary Medicine. 2014;4:1-6.

48. Lamikanra AA, Brown D, Potocnik A, Casals-Pascual C, Langhorne J, Roberts DJ. Malarial anemia: of mice and men. Blood. 2007;1 10:18-28.

49. Yang ZG, Sun HX, Fang WH. Hemolytic activities and adjuvant effect of Astragalus membranaceus saponins on the immune responses to ovalbumin in mice. Vaccine. 2005;23:5196-203.

\section{Submit your next manuscript to BioMed Central and we will help you at every step:}

- We accept pre-submission inquiries

- Our selector tool helps you to find the most relevant journal

- We provide round the clock customer support

- Convenient online submission

- Thorough peer review

- Inclusion in PubMed and all major indexing services

- Maximum visibility for your research

Submit your manuscript at www.biomedcentral.com/submit 